\title{
Fungsi Sosial-Kultural Sastra: Memajukan Kebudayaan dan Mengembangkan Peradaban
}

\author{
Redyanto Noor \\ Fakultas Ilmu Budaya, Universitas Diponegoro \\ redyanto_noor@yahoo.com
}

\begin{abstract}
There are three important social-cultural functions of literary works. First, the assumption that literary work is at the same level as the work of a priest or prophet. Second, the notion that the most important thing for the literary work is entertains. Third, the assumption that literary works should teach something with using entertaining system. The linkage of literary works to social-cultural systems can be further known by studying the value of relationships in literary works with the value of system in society. The value in literature is the system of social norms imposed in literary works, and the value of system in society is the norm system prevailing in the daily life of society. Ideally literary works should bring innovation, means renewal to the society. Therefore, the deviations of values in literary works do not imply the defiance of the standard conventions of social norms. Such deviations signify the creation of cultural dynamics, the establishment of new values. At the same time its open opportunities for people to move continuously, reconstructing thought to become more critical, analytical, and humanistic.
\end{abstract}

Keywords: Literary works, socio-cultural functions, values in the literary works, community value systems, innovation.

\section{Intisari}

Ada tiga fungsi sosial-kultural karya sastra yang penting. Pertama, anggapan bahwa karya sastra sama derajatnya dengan karya pendeta atau nabi. Kedua, anggapan bahwa yang terpenting bagi karya sastra adalah tugas menghibur. Ketiga, anggapan bahwa karya sastra harus mengajarkan sesuatu dengan cara menghibur. Kaitan karya sastra dengan sistem sosial-kultural lebih jauh dapat difahami dengan mempelajari hubungan antara nilai dalam karya sastra dengan sistem nilai dalam masyarakat. Nilai dalam karya sastra adalah sistem norma yang diberlakukan dalam karya sastra, dan sistem nilai dalam masyarakat adalah sistem norma yang berlaku dalam kehidupan masyarakat. Idealnya karya sastra harus inovatif, membawa pembaruan bagi masyarakat. Oleh sebab itu, penyimpanganpenyimpangan nilai dalam karya sastra tidak berarti pembangkangan terhadap konvensi tata nilai masyarakat yang baku. Penyimpangan-penyimpangan semacam itu menandakan terciptanya dinamika budaya, terbentuknya tata nilai baru. Sekaligus membuka peluang masyarakat bergerak terus-menerus, merekonstruksi pemikiran menjadi lebih kritis, analitis, dan humanistis.

Kata Kunci: Karya sastra, fungsi sosial-kultural, nilai dalam karya sastra, sistem nilai masyarakat, inovasi. 


\section{Pendahuluan}

Salah satu fenomena yang erat kaitannya dengan hakikat dan fungsi karya sastra adalah pertentangan faham-faham seni. Sejak lama sastra Indonesia mengenal pertentangan faham-faham seni. Salah satu contoh adalah pertentangan faham seni 'bertendens' dengan faham 'seni untuk seni'. Dengan berdirinya LEKRA, faham seni 'bertendens' dimodifikasi menjadi 'seni untuk rakyat'. Penganut faham 'seni untuk seni' meyakinkan bahwa kesenian murni jangan dicampuradukkan dengan tujuan propaganda, alasannya seni itulah sesungguhnya tujuan utama karya seni. Sebaliknya, penganut seni 'bertendens' menolak karya seni yang ditujukan hanya mementingkan seni. Mereka berpendapat karya seni diciptakan untuk tujuan kepentingan masyarakat mencapai taraf hidup yang lebih baik. Dengan demikian, faham 'seni bertendens' menuntut agar seniman memelopori bangsanya berjuang membangun dirinya. Menjelang akhir hayatnya Sutan Takdir Alisjahbana berpesan bahwa bangsa Indonesia yang begitu banyak tertinggal di segala sektor dari bangsa-bangsa lain harus memilih yang berguna, karena nasib bangsa di masa depan lebih penting dibanding nilai keindahan semata (Eneste, 1983:17). Sebagian orang berpendapat bahwa seni harus mementingkan kegunaannya, sementara sebagian yang lain berpendapat bahwa seni semestinya mementingkan seni itu sendiri.

Sesungguhnya tidak kurang upaya yang telah dilakukan para pemerhati sastra untuk memasyarakatkan sastra melalui berbagai kegiatan, tetapi persoalannya tidak semudah yang dibayangkan. Menurut Budi Darma, pada dasarnya sastra itu adalah dunia pemikiran, dan pemikiran itu adalah dunia minoritas (Darma, 1992:102-102 dan 110-111). Itulah sebabnya, mengubah tradisi berpikir tentang sastra, terutama hakikat dan fungsinya, menjadi gagasan penting yang dapat dikerjakan bersama oleh para sastrawan dan ahli sastra. Untuk itu, upaya 'berpikir menyimpang' tentang sastra menjadi salah satu gagasan yang menarik untuk diwacanakan dan diwujudkan.

\section{Hasil dan Pembahasan}

\section{Fungsi Sosial-kultural Karya Sastra}

Tidak dapat disangkal lagi bahwa karya sastra mempunyai hubungan yang erat dengan sistem sosial budaya. Sebagai salah satu artefak kebudayaan karya sastra berkaitan secara timbal-balik dengan artefak-artefak kebudayaan lainnya seperti bahasa dan bermacammacam karya seni. Selain itu, karya sastra juga berkaitan secara timbal-balik pula dengan sistem sosial yang mencakup sistem nilai dalam masyarakat: tradisi, pola pikir, falsafah 
hidup, sikap, perilaku, dan sebagainya. Hal itu terlihat jelas apabila sampai pada jawaban atas serangkaian pertanyaan: seberapa jauh nilai karya sastra berkaitan dengan sistem nilai dalam masyarakat?; bagaimana karya sastra berperan mengembangkan kebudayaan dan peradaban?; dan bagaimana pula karya sastra dapat dibentuk oleh nilai-nilai kebudayaan dan peradaban?

Berbicara tentang fungsi sosial karya sastra ada tiga hal yang perlu diperhatikan. Pertama, adanya anggapan bahwa karya sastra sama derajatnya dengan karya pendeta atau nabi. Dalam anggapan ini termaktub pendirian bahwa karya sastra harus mengajarkan sesuatu secara terus-menerus, merombak dan memperbarui tata nilai usang yang menyimpang. Kedua, anggapan bahwa yang terpenting bagi karya sastra adalah tugas menghibur saja. Dalam anggapan ini tertanam penilaian bahwa gagasan 'seni untuk seni' dalam karya sastra sesungguhnya tidak ada beda dengan praktik melariskan dagangan. Ukuran 'edi peni' karya sastra sebagai representasi gagasan dan pemikiran serta ukuran 'agung' gagasan atau pemikiran yang direpresentasikan dalam karya sastra adalah omong kosong. Ketiga, anggapan bahwa karya sastra harus mengajarkan sesuatu dengan cara menghibur. Dalam anggapan ini terpatri idealisme bahwa karya sastra selayaknya menempati kedudukan setinggi-tingginya karena kemampuannya menebarkan kemaslahatan bagi seluruh isi dunia (Damono, 2010:4).

Berkaitan dengan fungsi cultural sesungguhnya setiap karya sastra adalah hasil hubungan timbal-balik yang rumit dari faktor-faktor sosial dan kultural, dan sesungguhnya pula karya sastra itu sendiri adalah kultur yang rumit. Oleh sebab itu, sebuah karya sastra tidak dapat difahami selengkap-lengkapnya apabila dipisahkan dari lingkungan kebudayaan dan peradaban yang telah melahirkannya. Ia harus dipelajari dalam konteks seluas-luasnya (Noor, 2009:42). Seperti dikatakan Teeuw bahwa untuk memahami sebuah karya sastra dibutuhkan pengetahuan bermacam-macam sistem kode yang rumit. Selain kode bahasa dan kode sastra yang khas, tidak kalah penting adalah sistem kode budaya. Untuk memahami sastra Jawa misalnya, selain bahasa Jawa dan ciri-ciri khas sastra Jawa masih diperlukan pengetahuan tentang sistem budaya Jawa: tradisi, tata krama, simbol, kepercayaan, falsafah hidup, dan sebagainya (Noor, 2009:41).

Kaitan karya sastra dengan sistem sosial budaya lebih jauh dapat diketahui dengan mempelajari hubungan nilai dalam karya sastra dengan sistem nilai dalam masyarakat. Nilai dalam karya sastra adalah sistem norma sosial yang diberlakukan dalam karya sastra, 
dan sistem nilai dalam masyarakat adalah sistem norma yang berlaku dalam kehidupan masyarakat sehari-hari. Nilai dalam karya sastra yang sesuai dengan sistem nilai dalam masyarakat berarti tidak membawa inovasi bagi dinamika budaya, peradaban, dan pola pikir masyarakat. Idealnya karya sastra harus membawa inovasi, pembaruan bagi masyarakatnya. Oleh sebab itu, penyimpangan-penyimpangan nilai dalam karya sastra tidak selalu berarti pembangkangan terhadap konvensi tata nilai masyarakat yang baku. Justru penyimpangan-penyimpangan semacam itu yang menandakan terciptanya dinamika budaya, terbentuknya tata nilai baru. Sekaligus membuka peluang masyarakat bergerak terus-menerus, merekonstruksi pemikiran menjadi lebih kritis dan analitis.

Kaitan karya sastra dengan sistem sosial budaya, terutama fungsi sosial-kultural karya sastra, retrospeksinya dapat dilihat melalui perspektif sejarah kebudayaan sejak zaman primitif hingga sekarang. Pada masyarakat primitif sulit memisahkan karya sastra dari aktivitas keseharian; upacara keagamaan, ilmu gaib, permainan, dan kehidupan seharihari. Zaman sekarang pemisahan itu mungkin dapat dilakukan tetapi tidak mungkin sepenuhnya. Membaca sebuah cerita fiksi atau puisi masih memungkinkan orang memperoleh kenikmatan seperti yang diperoleh dari memainkan sebuah permainan. Orang boleh merasa lega sehabis membaca cerita fiksi atau puisi selega perasaan orang usai mengikuti upcara keagamaan. Apabila orang mampu memahami pesan yang terkandung dalam karya sastra batinnya lebih mantap menghadapi pekerjaan sehari-hari. Lebih jauh lagi, karya sastra dapat mengungkapkan gagasan yang mungkin dapat menumbuhkan sikap sosial tertentu (ingat: roman-roman adat Balai Pustaka, sajak-sajak revolusioner Angkatan 45, sajak-sajak antitirani Angkatan 66, novel-novel populer 70-an, dan sebagainya).

Sebagai bagian dari sistem sosial budaya, moral juga memiliki hubungan tak terpisahkan dengan karya sastra. Ada pendapat yang menyatakan bahwa karya sastra yang baik selalu membawa pesan moral kepada pembaca tentang kebaikan atau kebenaran. Pesan itu dinamakan moral, orang lazim menyebutnya amanat. Artinya sama, yaitu karya sastra yang baik selalu mengajak pembaca untuk menjunjung tinggi moral.

Budi Darma beranggapan betapa pun kecilnya ada kesamaan antara agama, filsafat dan karya sastra. Ketiganya berkepentingan mengurus persoalan manusia, yakni berkehendak mendidik manusia berjiwa halus, yang memenuhi hakikat, sifat dan fungsinya sebagai manusia, meskipun dengan cara yang berbeda-beda. Jika agama mengajarkan moral langsung dengan menunjuk pada kebenaran berdasarkan kesadaran dan keyakinan 
terhadap dogma; filsafat menunjuk pada kebenaran berdasarkan pemikiran hakikinya, maka karya sastra justru mengungkap realitas manusia yang seharusnya menurut moral tidak terjadi. Karya sastra adalah dunia jungkir-balik (Darma, 1984:47).

Berdasar anggapan itu Budi Darma menyimpulkan bahwa karya sastra yang lahir karena agama sudah mempunyai patokan-patokan yang jelas. Sesuai dengan ciri agama sebagai suatu dogma, nilai estetik yang diperjuangkan oleh karya sastra agama juga bersifat normatif, sebagaimana terlihat pada puisi para penyair religius (baca: sajak-sajak Amir Hamzah). Karya sastra begini adalah sarana pengucapan manusia untuk bertakwa, untuk memberikan pengakuan manusia akan keterbatasan-keterbatasan yang dimilikinya. Namun demikian, tidak sedikit karya sastra yang jelas-jelas bernafaskan keagamaan, baik berupa fiksi maupun puisi (Darma, 1984:53).

Sudut pandang mana pun yang dipakai sebagai titik tolak, sesungguhnya ukuran fungsi sosial-kultural karya sastra tetap berdasar pada keniscayaan sehingga kata 'kadar' menjadi penting artinya bagi pemahaman nilai-nilai dalam karya sastra. Konsep begini menjadikan karya sastra 'serius' dan karya sastra 'hiburan' harus ditempatkan pada kedudukan yang berbeda, pada posisi tinggi dan rendah, penting dan tidak penting, atau berguna dan tidak berguna. Meskipun begitu, sering dikatakan bahwa sesungguhnya setiap karya sastra pasti mempunyai fungsi sosial-kultural, betapa pun kecilnya.

Dari uraian di atas dapat dirangkum penjelasan bahwa karya sastra sesungguhnya adalah alat yang bersifat netral. Berfungsi atau tidak berfungsi bergantung pada kalangan yang berkepentingan dengannya (sastrawan, ahli sastra, kritkus sastra, masyarakat sastra). Sebagai alat, karya sastra bisa digunakan berbagai kalangan untuk berbagai kepentingan (uang, ketenaran, gagasan, keyakinan, pencerahan pemikiran). Persoalannya adalah bagamana tanggung jawab harus diberikan untuk setiap kepentingan oleh setiap kalangan yang menggunakannya? Tentu saja tanggung jawab itu ada pada sastrawan, kritikus sastra, dan masyarakat sastra, tetapi sesungguhnya yang paling bertanggung jawab adalah ahli sastra.

\section{Tanggung Jawab Sastrawan}

Fakta tentang manusia dan kehidupan dunia sekarang ini banyak dianggap sebagai gejala perubahan tata nilai yang telah mencapai titik kritis. Akibat lebih jauh dari perkembangan ilmu pengetahuan dan teknologi, sebagai hasil kerja keras manusia, merupakan lompatan- 
lompatan panjang yang setiap saat dapat mencelakakan diri manusia sendiri. Orang belum dapat mempercayai bahwa ancaman terbesar terhadap dunia dan kehidupan ini datang dari manusia sendiri. Orang tidak melihat fakta tentang dunia dan tata kehidupannya sendiri, apalagi memperhitungkan akibat lebih jauh dari keadaan yang sekarang sedang berkembang.

Menurut Mochtar Lubis, orang malah percaya bahwa ilmu pengetahuan dan teknologi bisa diumpamakan satu sisi lain dari mata uang yang dinamakan modernisasi. Jika tidak ikut dalam konsumerisme ilmu pengetahuan dan teknologi berarti tidak mengikuti arus modernisasi, dianggap ketinggalan zaman. Berarti pula tidak dapat mencapai tingkat kualitas hidup yang wajar, yang menjadi ukuran zaman ilmu dan teknologi modern (Noor, 1994:70). Untuk kepentingan masyarakat dan seluruh umat manusia mestinya makna modernisasi harus direkonstruksi. Apakah modernisasi itu hanya tecermin oleh peralatan teknologi modern semacam komputer, bioteknologi, roket, satelit, robot, dan sebagainya; ataukah modernisasi harus diartikan sebagai suatu sikap jiwa dan pikiran rasional yang selalu mencoba untuk mencari penyelesaian masalah-masalah hidup manusia secara menyeluruh dan manusiawi?

Mochtar Lubis mengemukakan satu contoh bahwa tuntutan untuk membuang berbagai teknologi yang dapat merusak ekologi, tata kehidupan, dan keberadaan manusia dianggap sikap paling modern dalam sepuluh sampai dua puluh tahun mendatang (Noor, 1994:71). Masalahnya adalah bagaimana menumbuhkan sikap seperti itu, dan bagaimana pula mengembangkannya secara umum dan menyeluruh? Untuk itu, mestinya perlu dicari nilai-nilai yang tumbuh dalam masyarakat itu sendiri, sebagai landasan sikap untuk mengendalikan pertimbangan-pertimbangan rasional Sebab, sekarang ini ada gejala manusia mulai kehilangan perspektif rasionalnya. Faktanya, posisi manusia yang telah 'tergencet' eksistensinya menimbulkan gejala-gejala manusia kehilangan nilai dan fungsinya sebagai manusia. Itu dapat dilihat melalui sebagian ciri-ciri masyarakat modern: rasa cemas, was-was, tidak bahagia, tidak tenteram, takut, gelisah, terasing dalam lingkungannya, kehilangan hubungan mesra perseorangan dan keluarga, dan sebagainya. Salah satu unsur dekat masyarakat dan mempunyai nilai-nilai yang tumbuh di dalamnya adalah berbagai artefak budaya, misalnya kesenian.

Bermacam-macam bentuk kesenian, tidak terbatas kreasi baru atau tradisional, semuanya membawa nilai-nilai (sense) yang lebih realistik dan rasional, meskipun 
umumnya diungkapkan dalam wujud simbol atau lambang. Tradisi, kepercayaan, tata krama, mitos, upacara-upacara ritual, dan sebagainya memang mengikat manusia untuk tetap memanfaatkan (bukan mematuhi) kaidah-kaidah normatif yang berlaku. Demikian pula seni lukis, seni tari, seni musik, dan seni sastra. Karya sastra modern dan klasik samasama memberlakukan norma-norma kebenaran yang layak dihayati dan dimanfaatkan masyarakat. Jika masyarakat dapat memahami isinya, menangkap maknanya, menyerap nilai-nilai yang dikandungnya, kemudian menghayati dan menerapkannya, maka mereka tidak akan jatuh dari kedudukan sentralnya sebagai manusia.

Mencermati begitu pentingnya fungsi karya sastra sebagai pemerkaya pengalaman spiritual (batin, jiwa) manusia, maka muatan di dalamnya harus sarat dengan nilai. Itulah sebabnya, tanggung jawab sastrawan sebagai pencipta karya sastra menjadi beban yang tak ada batasnya. Sastrawan seharusnya adalah orang yang peduli kepada perkembangan ilmu pengetahuan, teknologi, serta kebudayaan dan peradaban manusia di muka bumi, yang selalu mengemukakan modernisasi sikap berbudaya dan beradab di dalam karya-karyanya. Ia harus rasional menghadapi segala persoalan hidup manusia, dan ia harus melakukan analisis tajam sebelum menentukan pilihan untuk mengatasinya. Bagi sastrawan, karya sastra bukan sekadar barang seni yang cukup memenuhi kebutuhannya sendiri. Karya sastra harus dihasilkan dari bahan-bahan yang dikumpulkan oleh bermacam-macam ilmu dan pengetahuan, yang berupa fakta, data, dan abstarksi-abstraksi yang terjalin bersamasama ekspresi perasaan dan keinginan hakiki sehingga di dalamnya terjelma suatu tanggung jawab dan kebulatan niat manusia yang sadar akan martabatnya.

Untuk mencapai itu seharusnya para sastrawan berani mengambil inisiatif. Sebab, sekarang ini kesusastraan mempunyai tugas yang luar biasa besarnya karena perkembangan kebudayaan dan peradaban manusia akibat lompatan kemajuan ilmu pengetahuan, teknologi, dan ekonomi. Jika kesusastraan dengan sadar mampu menghadapi persoalan-persoalan itu, ia sesungguhnya akan sangat berperan dalam perkembangan sejarah dan kebudayaan manusia. Sebab, tak dapat disangkal umat manusia sekarang ini sedang mengalami transformasi mahabesar justru karena sikap, perbuatan, dan "pokal" nya sendiri.

\section{Tanggung Jawab Ahli Sastra}


Dalam kehidupan masyarakat, karya sastra berada pada posisi marjinal, tidak banyak diperhatikan. Ini tidak hanya terjadi di Indonesia dan negara-negara berkembang lainnya, tetapi juga terjadi di negara-negara maju seperti Inggris, Perancis, dan Amerika. Persoalannya terletak pada faktor penyebabnya, yang berbeda antara satu negara dengan negara lainnya. Masyarakat Indonesia belum menganggap sastra sebagai kebutuhan. Masih banyak hal lain yang lebih penting, misalnya ekonomi, politik, hukum, pendidikan, kesehatan, dan lain-lain. Jika ada kelompok yang ekonominya kuat, maka mereka memilih dunia yang 'mudah', yang tidak memerlukan pemikiran. Jika mereka membaca sastra, tentu karya sastra yang 'mudah', karya sastra yang memberikan suasana santai.

Keadaan itu sesungguhnya wajar karena memang apresiasi sastra masyarakat masih rendah, dan kebanyakan karya sastra di Indonesia juga tidak komunikatif. Jadi, rendahnya apresiasi sastra masyarakat tidak berarti masyarakat bodoh. Tentu saja sastrawan juga harus mawas diri, mengapa karya sastra tidak komunikatif? Mengapa masyarakat tidak menganggap penting karya sastra? Ada dua faktor penting. Pertama, meskipun berbentuk cerita tetapi karya sastra pada dasarnya adalah dunia pemikiran sehingga karya sastra itu 'sulit'. Oleh sebab itu, karya sastra pada umumnya tidak komunikatif. Kedua, banyak karya sastra Indonesia yang 'sulit' bukan karena pemikiran pengarangnya yang rumit atau gagasannya yang besar, tetapi cara ekspresinya yang lemah. Karya sastra pada tidak laku karena memang tidak mampu menjangkau peminat yang lebih luas, meskipun dengan mutu yang tinggi. Yang penting bukan menyalahkan masyarakat, tetapi melakukan koreksi diri. Sastrawan perlu mempertanyakan kembali ide-ide mereka, juga cara menuliskannya.

Dari sekian banyak persoalan sastra, yang paling penting adalah fungsi dan kedudukan ahli sastra. Keberadaannya tenggelam di antara malang-melintangnya para ahli bidang lain. Gagasan dan tulisan mereka terhapus oleh hiruk-pikuknya gagasan dan tulisan para ahli bidang lain (ahli politik, ekonomi, teknologi, kebudayaa, agama, olahraga, kecantikan, dan lain-lain). Akibatnya, gagasan dan tulisan para ahli sastra hanya dikonsumi oleh dan untuk diri mereka sendiri. Padahal sebagian tugas memasyarakatkan sastra menjadi tanggung jawab ahli sastra, bukan sepenuhnya menajdi tanggung sastrawan. Tugas melariskan karya sastra sebagai barang dagangan memang wewenang penerbit, tetapi tugas menumbuhkan kesadaran dan memahamkan pengertian kepada masyarakat bahwa karya sastra sebagai sumber nilai-nilai tuntutan hidup sesungguhnya menjadi tanggung jawab para ahli sastra. 
Jika sekarang puisi masuk hotel berbintang, mal atau café; cerita pendek dibaca di gedung kesenian; novel terpampang di etalase books store, bukan karena buah kerja para ahli sastra. Beberapa sastrawan secara perorangan atau kelompok telah bekerja keras membentuk jaringan demi menarik perhatian masyarakat terhadap karya sastra. Beberapa pekerja sastra, yang bukan ahli sastra, melalui komunitas masing-masing telah bekerja keras mewacanakan keberadaan karya sastra kepada masyarakat luas. Jika beberapa waktu yang lalu puisi dapat dibaca di GKJ dan $J C C$ dengan animo penonton yang begitu besar, ucapan terima kasih mestinya ditujukan kepada artis yang membacakannya. Sekalipun dalam pementasan itu perhatian penonton belum sungguh-sungguh tertuju pada keinginan memahami dan mencerna nilai-nilai puisinya tetapi baru sebatas menikmati penampilan pembacanya. Akan tetapi, setidak-tidaknya masyarakat mengetahui bahwa karya sastra itu ada dan menyenangkan pula.

Barangkali sekarang berdiskusi tentang sastra tidak harus mengundang ahli sastra, dosen sastra, peneliti sastra, kritkus sastra, dan sastrawan. Sekarang berbicara tentang sastra kepada politikus, ekonom, teknokrat, birokrat, terutama para pengusaha lebih relevan dibanding grenengan di antara sesama anggota masyarakat sastra (seperti KIK ini?). Paradigma penilaian masyarakat tentang fungsi sastra telah berubah. Upaya mencerahkan pemikiran bangsa dan umat manusia tampaknya tidak lagi dianggap menjadi tanggung jawab sastra. Bidang sains dan teknologi dianggap lebih berperan mencerahkan pemikiran bangsa justru karena sains dan teknologi lebih memudahkan mereka mengatasi problem-problem kehidupan sehari-hari. Namun, sebagian besar masyarakat tidak sadar bahwa sumber inspirasi atas pemecahan problem-problem mereka sesungguhnya ada pada orientasi sikap, bukan pada alat yang namanya sains dan teknologi. Untuk itu, tradisi berpikir analitis dan kritis sesungguhnya menjadi penting artinya bagi upaya menentukan orientasi sikap. Pencerahan pemikiran manusia menjadi titik tolak melapangkan jalan manusia mencapai hakikat kemanusiaanya, dan karya sastra sebagai wujud ekspresi gagasan dan pemikiran manusia merupakan salah satu alat pengasah sikap-sikap humanitas menjadi lebih halus, lembut, dan menakjubkan. Sekarang, tugas ahli sastra adalah memahamkan makna itu tidak saja kepada sebuah bangsa, tetapi kepada seluruh umat manusia.

\section{Simpulan}


Dari uraian di atas secara ringkas dapat dikemukakan beberapa gagasan sederhana mengenai fungsi sosial-kultural karya sastra dan relevansinya di masa kini.

1. Akibat perkembangan ilmu pengetahuan dan teknologi yang dahsyat sekarang ini, kebudayaan dan peradaban dihadapkan kepada keadaan krisis. Manusia kehilangan orientasi dan identitas kemanusiaannya, manusia kehilangan kendali atas sikap dan perilakunya karena meninggalkan kultur normatif idealnya.

2. Untuk mengembalikan manusia kepada kedudukan sentralnya perlu dikembangkan nilai-nilai sosial-kultural dengan konfigurasi baru, yang mudah diserap dan diungkapkan kembali dalam bentuk sikap dan perilaku yang ideal.

3. Nilai-nilai sosial-kultural itu sebagian dapat digali dari karya seni, salah satunya adalah karya sastra, sesuai dengan fungsinya sebagai pencerminan gagasan dan pemikiran individu atau kolektif. yakni sebagai salah satu alat pengesahan pranata sosial-budaya, serta orientasi sikap dan perilaku, agar norma-norma masyarakat berkembang dinamik tanpa harus kehilangan hakikat humanitasnya.

4. Upaya mengembangkan fungsi sosial-kultural sastra adalah membangkitkan kembali nilai-nilai ideal-rasional humanisme sebagai orientasi sikap dan perilaku masyarakat modern. Salah satu caranya adalah menyebarluaskan karya sastra agar diketahui, dibaca, difahami, dihayati, dan dibutuhkan oleh masyarakat. Dalam konteks mengupayakan ini tidak ada yang lebih bertanggung jawab selain para ahli sastra dan sastrawan.

\section{Daftar Pustaka}

Alisjahbana, Sutan Takdir. 1977. Perjuangan Tanggung Jawab dalam Kesusastraan. Jakarta: Balai Pustaka.

Damono, Sapardi Djoko. 2010. Sosiologi Sastra: Sebuah Pengantar Ringkas. Ciputat: Editum.

Darma, Budi. 1984. Sejumlah Esei Sastra. Jakarta: Karya Unipress.

Darma, Budi. 1992. "Bangsa Indonesia Mengalami Kekosongan Jiwa” dalam Amanah, No. 141, Desember 1992, hal. 102-103 dan 110-111.

Eneste, Pamusuk (ed.). 1983. Proses Kreatif: Mengapa dan Bagaimana Saya Mengarang, Jilid I. Jakarta: Gramedia. 
Junus, Umar. 1983. Mitos dan Komunikasi. Jakarta: Sinar Harapan.

Kartodirdjo, Sartono. 1986. "Fungsi Humaniora dalam Pembangunan Nasional", Kompas, 26 dan 27 Februari 1987.

Lubis, Mochtar. 1980. Manusia Indonesia: Sebuah Pertanggungjawaban. Jakarta: Yayasan Idayu.

Noor, Redyanto. 1994. "Mencari Relevansi Antara Kebangkitan Dominasi Nilai-nilai Folklor dengan Orientasi Sikap Masyarakat Modern" dalam Jurnal Ilmiah Lembaran Sastra Edisi Khusus No. 17. Semarang: Fakultas Sastra UNDIP.

Noor, Redyanto, 2000. "Rasionalisme-Empiris Melawan Mitos: Muatan Filsafat Novel Kalah dan Menang" dalam Jurnal Ilmiah Kajian Sastra No. 4. Semarang: Fakultas Sastra UNDIP.

Noor, Redyanto, 2001. "Pemerolehan Fungsi Gemar Membaca Cerita Fiksi Bagi Pengayaan Pengalaman Rohani dan Sikap Sosial Wanita Kota" makalah Diskusi Rutin, 28 September 2001, Fakultas Sastra UNDIP.

Noor, Redyanto. 2009. Pengantar Pengkajian Sastra. Cetakan ke-3. Semarang: Fasindo.

Teeuw, A. 1983. Membaca dan Menilai Karya Sastra. Jakarta: Gramedia. 